EASTERN REVIEW 2020, T. 9

\author{
Victor Nitsevich \\ (iD https://orcid.org/0000-0002-1668-3067 \\ Moscow City University, Moscow, Russian Federation \\ Department of State and Municipal Administration and Law \\ e-mail: dr.nitsevich@mail.ru
}

\title{
Subjective grounds for expanding the powers of the President of the Russian Federation
}

\begin{abstract}
The article is devoted to a little-studied side of authority, in particular the authorities of the President of Russia. Exploring the constitutional scope of power, we can say that the President of Russia has a sufficiently large amount of power, backed up by the legal provisions of the Constitution. However, in practice, it has turned out that not only their influence but the power of the President has a wider scope. First of all, the article notes the subjective grounds and mechanisms of power over the chairman of the government and the terms of his appointment. In this case, the key role is played by the political party United Russia, which was created by the President, although the President is outside the party system of Russia. A substantial expansion of the power of the President occurred as a result of the creation of federal districts and the formation of an institution of plenipotentiaries. The rationale is given that the change of legal norms for the election of governors, where the President plays the main role in nominating candidacy, and the procedure for registering them is entirely determined by the United Russia political party under his control, ultimately expanded the scope of authority of the President. In disclosing the subjective grounds for expanding the power of the President of the Russian Federation, so-called "approvals" of candidacy for various senior positions of state and municipal service, as well as of the security and control bodies play a part. The rating of the President was a massive subjective basis that allowed him to expand the scope of his power. The study of public confidence in the President allowed one to see the dependence of the expansion of his power on the level of his support by citizens of the Russian Federation.
\end{abstract}

Keywords: President, authorities, plenipotentiaries, political parties, public confidence, election of governors. 


\section{Introduction}

First of all, we should research the constitutional powers, because it is through them that it is possible to see the expanding volume of power. The powers of the President are determined by the Constitution of the Russian Federation and the scope of such powers must be comprehensive.

According to Article 83 of the Constitution of the Russian Federation the President has the following powers towards the Government of the Russian Federation:

- to appoint the Chairman of the Government with the consent of the State Duma. Moreover, in the case where the State Duma rejects three times the candidacy nominated by the President for the post of the Chairman of the Government of the Russian Federation, he can dissolve the State Duma and call for new elections;

- to chair meetings of the Government of the Russian Federation, to determine the main directions of the domestic and foreign policies of the State;

- to dismiss the Government in some cases: Government submission of resignation, State Duma's expression of no-confidence in the Government of the Russian Federation.

The President of the Russian Federation has special powers provided by this Article. According to that, he has the right to appoint and dismiss federal officials of the Russian Federation.

Regarding legislative power (Article 84) the President has a right to:

- announce elections to the State Duma;

- use conciliatory procedures and other methods for overcoming crises and solving disputes among the three Power Branches, which are the levels of government as well;

- announce a referendum, which, along with free elections, is the highest direct expression of the public will;

- submit bills to the State Duma;

- make proposals on amendments and review the provisions of the Russian Constitution.

The President of the Russian Federation has special powers to govern the foreign policy of the Russian Federation. They are:

- to hold negotiations and sign international treaties and agreements of the Russian Federation;

- to receive credentials and letters of recall of diplomatic representatives accredited to him;

- to sign international agreements.

As the Supreme Commander-in-Chief of the Armed Forces of the Russian Federation, the President of the Russian Federation shall: 
- determine the guidelines of the military policy of the State;

- govern Russia's military structures;

- appoint and dismiss the supreme command of the Armed Forces of the Russian Federation.

The President holds the final word in any issues of citizenship of the Russian Federation and of granting political asylum.

Other powers of the President include the following:

- to issue decrees and orders, which are classified as regulatory and individual. However, the Constitution does not define exactly on which issues (on constitutional powers or on any others);

- to introduce a state of emergency in the territory of the Russian Federation or in its certain parts, with the proviso that he must immediately inform the Council of the Federation and the State Duma about this;

- to decorate individuals with state awards of the Russian Federation;

- to pardon specific individuals.

Strictly speaking, the powers mentioned above constitute the authority of the President (Constitution of the Russian Federation, 2018). However, the practice of rule shows that in addition to formal, above all, legal powers, there are other possibilities to rule. This means that there are opportunities to expand the scope of the power of the President without changing the Constitution of the Russian Federation.

According to the opinions of many researchers, the powers of the President of the Russian Federation have already been expanding for some years (Guseva, Pavlova, 2018).

It is obvious that power is always a process of interaction among people, human groups. In the process of such interaction, a subjective power appears, something that flows and depends on specific people, officials. In this regard, it is the subjectivity in the expansion of the power of the President that is of theoretical and practical interests.

In this case, the most important subjective grounds are:

- the subjective choice of candidacies for the post of the Prime Minister and his Deputies, Federal Ministers, the Head of the Central Bank, the Prosecutor General, the Chairman of the Supreme Court and other officials;

- the possibility of creating Federal Districts and the subjective choice of Plenipotentiaries in these districts, as well as the appointment of Plenipotentiaries to the State Duma and the Federation Council;

- the subjective choice of candidacy for the post of governors (heads of regions);

- the creation of the "institution of coordination" for the appointment of key positions;

- subjective influence on the party system;

- formation of the level of public confidence. 


\section{Expansion of the powers of the Russian Federation's President from the perspective of a presidential form of a constitutional regime}

Let us consider the above-mentioned subjective grounds for the expansion of the powers of Russia's President.

Practically the President, having the absolute parliamentary majority of the All-Russian political party "United Russia", headed by Prime-Minister D. Medvedev, fully demonstrates subjectivity in the appointment of the Prime-Minister of the Government of the Russian Federation (Nevinskiy, 2018). The Chairman of the Government is proposed by the President of the Russian Federation and must be approved by the State Duma of the Russian Federation. However, experience has shown that not all candidacies were approved by the State Duma. For example, in December 1992, the Congress of People's Deputies refused to approve the candidature of Yegor Gaidar for the position of Prime-Minister of Russia's Government due to dissatisfaction with the course of economic reforms (Gavrilko-Alekseev, 2018).

It was this experience that stimulated the subjective additions to the legal mechanisms introduced by B.N. Yeltsin to the Constitutional Meeting. The issues of the formation of the Head of Government were as follows: the Chairman of the Government of the Russian Federation was to be appointed by the Council of the Federation within two weeks after the nomination by the President of the Russian Federation. In the case that the Federal Council of the Federal Assembly of the Russian Federation rejects the candidate nominated by the President of the Russian Federation, the latter, within a week, submits a new candidate to be approved by the Federal Council. If the Federal Council rejects the candidate submitted by the President for the second time then the President submits a candidate for the Prime-Minister to both Chambers of the Federal Assembly for their joint consideration. In this case, the appointment of the Head of the Government shall be not later than a month from the date of the candidate's submission by the President. If during this period the Chairman of the Government was not appointed by the Federal Assembly, the President could make a decision on the early dissolution of the Federal Assembly and the appointment of an Acting Prime-Minister (Article 106).

The advantage of this model, in comparison with the Soviet ones, was that the question of the formation of the position of the Head of the Government, and the whole Government as well, were resolved in the context of the separation of powers and the system of checks and balances with the use of the institution of parliamentary dissolution. It proves how important the position of the Head of the Government is. Regarding its disadvantage, the downside is that the Federal Council took a very decisive role in the appointment of the Prime-Minister of the Russian Federation, which functionally was not adapted to the formation of a Government. 
In the aftermath of the changes, the questions of the formation of the position of the Chairman of the Government of the Russian Federation became a subject of heated debate at the Constitutional Conference. A lot of participants of the meeting proposed providing the President of the Russian Federation with the right to appoint the Prime-Minister. These proposals were made in the context of a discussion concerning the formation of a semi-presidential system where the Head of the State forms the Government.

To that end, during the meeting of the Working Commission on finalizing the draft of the Russian Federation's Constitution of June 22, 1993, the Director of the Institute of State and Law of the Russian Academy of Science, B.I. Toporin, noted:

First of all, we have a question if the State Duma or the Parliament need to appoint the Chairman of the Government?... The appointment of the Chairman should not be a matter for the Parliament because it puts too much responsibility on the Parliament; imposes and changes, in general, the system that we took here as the original one (Krasnov, Shablinskij, 2008: 27).

In the final edition of the new Constitution of the Russian Federation, the formula of appointment of the Chairman of the Government of the Russian Federation acquired the following form: the Chairman of the Government of the Russian Federation shall be appointed by the President of the Russian Federation with the consent of the State Duma (part 1, Article 111, Constitution of the Russian Federation).

This form is generally consistent with the presidential-parliamentary rule, where a government is formed by the Head of the State with the indirect participation of parliament.

The advantage of this model is that the position of the Head of Government is formed with the participation of different power branches of government, which ensures the relative independence of this State figure.

The proposal of the candidate for the Prime Minister of the Russian Federation is made by the President no later than two weeks after taking office, following a presidential election; or after the resignation of Russia's Government; or within a week from the date of the rejection of a candidate for the Chairman of the Government by the State Duma (part 2 Article 111). The State Duma must consider the candidate for the Chairman of the Government submitted by the President of the Russian Federation within a week from the date of submission (part 3). In the case where the State Duma rejects three times the candidates for the post of the Chairman of the Government of the Russian Federation, the will President dissolve the State Duma and call new elections (part 4).

The obvious lack of a constitution mechanism ensuring the formation of the post of the Head of the Federal Government is the lack of a fixed term for the dissolution of the State Duma in the case of the triple rejection of the 
candidates submitted by the President. It can delay the process of dissolving the Lower House or, on the contrary, make it transient, precluding the parties from reaching a compromise that could help to avoid parliamentary dissolution.

The decision of the State Duma to give consent to the appointment of the Chairman of the Government of the Russian Federation is made at the discretion of the State Duma through a secret ballot or using an electronic vote-counting system or open voting if such a decision is made by the majority votes of the total number of deputies of the State Duma. The consent of the State Duma to the appointment of the Chairman of the Government of the Russian Federation is considered received if the majority of the deputies of the State Duma voted for the proposed candidate (Article 146).

In the case where the State Duma twice rejects the proposed candidates for the post of the Prime-Minister of the Government of the Russian Federation, within a week from the date of the rejection of the second candidate, the President has a right to submit the third candidate. Discussion about and approval of the third candidate for the post of the Prime-Minister of the Government of the Russian Federation takes place according to the procedures for the discussion and approval of the previous candidates (Article 148).

In practice, the President presents his candidate to the State Duma by a special letter addressed to the Chairman of the State Duma, who reads it out at a Plenary Session of the Chamber. However, to submit a candidate for the post of Prime-Minister of the Government of the Russian Federation on May 8, 2008, the President of the Russian Federation Dmitry Medvedev personally participated in the Plenary Session of the State Duma of the Russian Federation. Such a step was unprecedented.

First of all, D.A. Medvedev is the Chairman of the party United Russia that maintains a dominant position in the State Duma. It automatically means the consent of the State Duma with this candidate by virtue of party discipline. However, even if the President submits a different candidate, a mechanism of the provisional elections of this candidate as a chairman of the United Russia Party may work due to the strong prestige and impact of the President, or the State Duma may approve it to stop the President from dissolving the State Duma after three rejections of the candidates by the President, or if the Party United Russia supports a non-party candidate as it happens at the regional elections. This can be seen in the fact that despite the strong dissatisfaction of the population with D.A. Medvedev, and the demands of his dismissal, the President did not change the Prime Minister (Lebedintsev, Isakov, 2018).

An important subjective basis for expanding the scope of the power of the President is that the President appoints Deputy Prime-Ministers and ministers (Chepus, 2015). For example, It is well known that the President appointed O.Yu. Vasilyeva as the Minister of Education and Science of the Russian Federation without coordination with the Government. 
Certainly, the power of the President is expanded by the appointment of the Ministers of the "power bloc", practically from due to his own subjective considerations.

Furthermore, the President appoints some key executives, among them: the Head of the Central Bank, the Prosecutor General, the Chairman of the Supreme Court, and other officials. On the one hand, this is his legal right, but on the other hand, the President makes such appointments, regardless of the preferences of the political party that won the parliamentary elections. This means that the winning party's power is limited, and, perhaps more worrying, the President's subjectivity can create a crisis.

With such subjective influence of the party system, creating the vertical power, the President got an opportunity to dominate the political parties. This became possible through regulatory, administrative, and organizational measures, as well as through the strengthening and domination of the United Russia party. In the framework of this process, there was an attempt to establish a two-party system (United Russia and Fair Russia) which unfortunately failed. However, it allowed the Communist Party of the Russian Federation and the Liberal Democratic Party to gain influence, both parties which cautiously criticize the President.

Since the non-parliamentary opposition does not even have a majority in any legislative assembly, they are forced to get some permissions in order to maintain the visibility of their influence in front of the electorate. Alas, the price of that is the avoidance of any sharp criticism and demands on the President.

Thus, several governors who were representative of the parliamentary opposition got appointed. Besides, the United Russia party did not nominate its candidate in the elections and asked people to vote for the Presidential appointee. It proves the existence of "agreements" regarding the political struggle between the President and political parties.

\section{The expansion of the power of the President of the Russian Federation from the perspective of federal relations in Russia}

The expansion of the power of the President was accompanied by the formation of the Federal Districts which are not stipulated by the Constitution of the Russian Federation regarding territorial division. However, such districts were established by a presidential decree. Such a step subjectively expanded the scope of his power. The Federal Districts are not the subjects or any other constitutional part of the administrative-territorial division of the Russian Federation and were created as if analogous with military districts and economic regions, but did not coincide with their number and composition (Cherkasov, 2008). 
However, the Districts, or rather, the Representatives of the President in the Districts, are charged with the task of monitoring, influencing, and evaluating the activities of the authorities in the regions of the Federation located in the Federal Districts, and coordinating candidates for a number of key positions.

At the same time, the President subjectively appoints these Presidential plenipotentiaries. The political parties, governors, or mayors of cities do not participate in this process. These are the sole decisions of the President (Abaeva, 2016).

The main tasks of the Presidential Plenipotentiary are:

- the organization of the activities of the regional authorities aimed at implementing the directions of national and foreign policies determined by the President;

- control over the implementation of decrees of the government apparatus of the Federal Districts;

- assistance in the implementation of staff policy as determined by the Head of the State for the Federal Districts;

- regular reports to the Head of State about the level of national security in the Federal District, the social, economic, and political situation in the region (Abdulbarova, 2019).

It is important to emphasize that a plenipotentiary, not having a regulatory function, is able to impact the decision made by the President: including both the appointment of and dismissal of officials.

The competences of the Presidential Plenipotentiary includes the following functions:

- the coordination of the work of the executive power of the region;

- analysis of the effectiveness of regional law enforcement bodies;

- building a dialogue-bridge between the federal executive power and the governing apparatus of the region, local governments, political parties, religious and public associations;

- assistance in developing a program for the economic and social development of a Federal District;

- approval of candidates for the federal civil service, but only if this appointment is made by the Head of the State;

- approval of those decisions of the executive power of Federal Districts, which are in the interests of the whole region or its part;

- delivery of a certificate to federal judges in a number of arbitration courts;

- appeals to the President with an initiative to award officials of the executive office of a Federal District; approves awarding documents as well as personally gives certificates of merit, awards, conveys gratitude from the President;

- taking part in the work of regional State bodies, local government bodies;

- agreement of a candidate to Cossack detachments (Atamans). In the case where acts of local legislative power are contrary to the Constitution, federal laws, decrees of the President, then a Presidential Plenipotentiary sends a proposal to the Head of State to suspend these decisions (Abdulbarova, 2019). 
It is obvious that a Presidential Plenipotentiary has a very wide power in a Federal District. Furthermore, although the participation of a Presidential Plenipotentiary in the work of the State Duma and the Federal Council is not provided for by the Constitution, they appeared on the basis of the President's Decree to impact the legislative process or other questions by representing the President's position. It is very difficult to imagine that the dominant political party, United Russia, will place itself contrary to the position of the President.

The election of governors is another subjective basis for expanding the power of the President. Further to that, Articles 71, 72, 73 of the Constitution of the Russian Federation establishes the areas of jurisdiction as well as the joint areas of jurisdiction. That means that the population is free to choose the way to fill the post of governor. Initially, it was like that. During the period 1996-2004 the elections of heads of Russia's subjects (regions) were held in all subjects of Russia, with the exception of Dagestan (where the national elections were supposed to be held in 2006, but were cancelled due to changes in federal law. As a rule each $4-5$ years a governor was elected by direct and secret ballot. But the requirements for candidates allowed the nominating of citizens who were not always desirable for the Federal Government. Furthermore, there were also excesses and not always worthy and effective candidates got to be governors.

Therefore, in September 2004, the President of Russia came up with an initiative to change the procedure of empowering senior officials of the Federation's subjects, proposing the approval of them by decisions of legislative bodies based on the President's proposals. The selection of candidates was subjective, no objective criteria were made public. As a rule, the main and passable candidate was accompanied by two other impassable candidates. This was how the mechanism of the appointment of senior officials of Russia's regions worked.

In April 2012, at the initiative of the successor, D.A. Medvedev, the Federal Law on the return of direct elections of the regional Heads was adopted.

First, subjectively, according to the law, the President of the Russian Federation independently determines the need and procedure for holding consultations on candidates for governor and not only with parties offering candidates for this post, but also with self-nominated candidates.

Secondly, candidates must pass the municipal filter (5-10\% of municipal deputies or Heads of municipalities in the Moscow Region and get $3 / 4$ support in the municipalities or Heads of municipalities); that is another subjective mechanism where the main role is played by attitudes in a political party.

Self-nominated candidates for registration at the elections have to collect from $0.5 \%$ to $2 \%$ (at the discretion of the region) voter signatures in their support.

Besides, there is one more practice, as a rule, the President appoints acting governors who work until the elections. As a result of this subjective selection, the President influences the election of heads of regions. In fact, until 2018, the choice of the President was confirmed by the population's election. 
The impact of the subordination of the party system was vividly characterized by V.G. Semenova. Thus, despite keeping liberal rhetoric, the democratic procedure of citizens to elect and to be elected is very limited. This fact is proved by the introduction of various unconstitutional barriers at the nomination stage, the effect of "municipal" and "presidential" filters, control by higher authorities and so on. In fact, the main result of the adoption of the researched Law can be full predictability of elections at all stages. Moreover, this predictability can be ensured in the legal field without gross violations such as the falsification of votes: with the refusal of registration, the inability to overcome the "municipal filter", unequal access of candidates to the media and other similar measures. As a result, political elites will keep control over elections and political activity in the State (Semenova, 2014).

With regard to the creation of the "approval procedure" for appointing people to key positions, it should be emphasized that approval procedures have no the legal implementation at the federal level, but have at the regional one. Thus, the candidates to the Deputy-Governors are approved by the legislative assembly. Since the majority of representatives in the legislative assemblies are the representatives of the United Russia political party, it is obvious that not all candidates can pass this subjective filter.

Of course, the approval procedures are available in almost every ministry, department, at the federal, regional and municipal levels. Such procedures are held not only to place people in the positions of the civil (municipal) service, but also for other ones. For example, for a candidate to become a rector of a university they must be approved by the regional head and afterwards by the Presidential Plenipotentiary in the federal district. That said, such approvals are within the system of the vertical power of the President, therefore, the "approvals" can be viewed as a subjective extension of the President's power.

\section{The level of public confidence as a subjective basis for expanding the powers of the President of the Russian Federation}

The level of public confidence in the President is a very important subjective basis. The public confidence in the President is still one of the most important factors to legitimise the power of the governors (Semenova, 2014).

The Russia Public Opinion Research Center presents electoral confidence ratings in politicians and evaluations of the activities of State bodies, which indicate that the approval rating of the President's activities is consistently high. When answering an open question the answer comes: "All of us trust one, and do not trust others". And when talking about politicians, and asking whom the public trusts, and who would not be entrusted with solving important State issues, 50.1\% 
of Russians named Vladimir Putin (VTsIOM) as being someone they could trust with decision making. These are the results of a poll conducted from August 28 to September 3, 2017, among 4,200 people in 80 regions. Approval of the activities of the President in August 2017 was on average at 83.5\%, whilst according to the data from August 28 to September 3,2017, it was 84.4\% (Kondratenko, 2017).

The confidence coefficient in relation to the President of The Russian Federation is considered as the difference between the part of the population who have confidence in the President and the part of the population who have none. The dynamics of the confidence coefficient is presented in Figure 1. In the period 2003-2006, the results of the two polls overlap in time and are different a bit. Therefore, this period is presented with a dotted line.

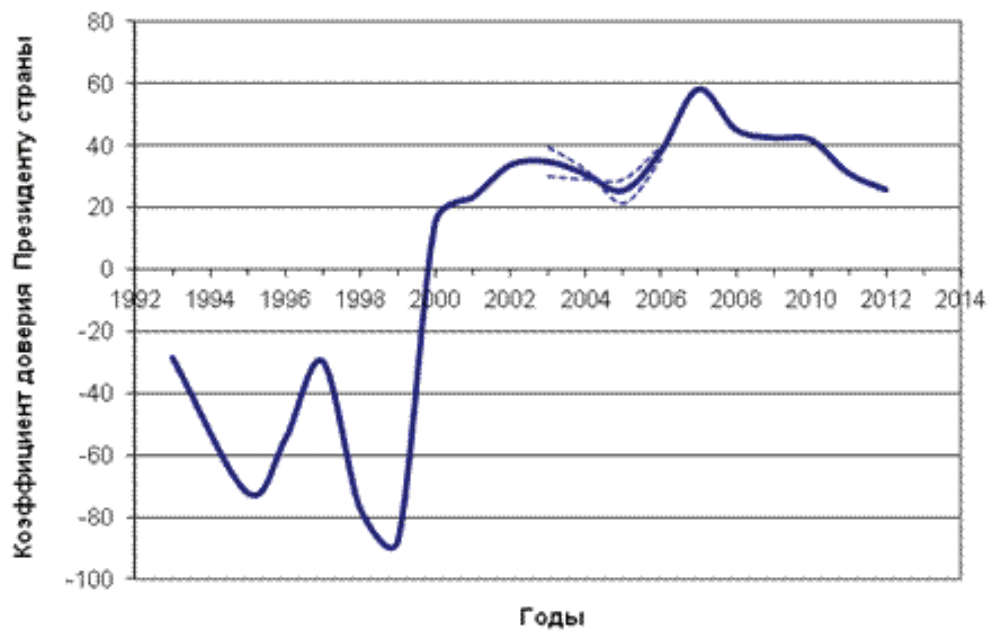

Figure 1. Public Confidence in the President of the Russian Federation Coefficient Sources: Perov, 2014.

As a result, it is visible that until 2000, the attitude towards the current President of the country (B.N. Yeltsin) was negative. This has its explanation. B.N. Yeltsin's activities aimed to destroy the existing economic system. However, this period was delayed and the population was tired of economic and political uncertainty, lower incomes and unemployment. After the election of V.V. Putin as President of Russia, and until the end of the analysed period, although the attitude towards the current President changed, they remained generally positive.

The attitude of the population towards the Government is reflected by the indicators characterizing trust and approval of its activities. The level of confidence in the Government of Russia was monitoring by various sociological polls between 1993-2006. Respondents answered the question "To what extent, in your opinion, is the Government of Russia credible?" They chose one of the poll's answers - not credible at all; not very credible; very credible; hard to answer. The 
approval of the current Government has been evaluated since 2003. Respondents answered a question which reflected the approval of its activities. In this case, the proposed answers were the following: definitely, yes; rather, yes; probably not; certainly not, hard to answer.

The greatest confidence in the Government (fully credible) was noted in 2008. However, this year demonstrated that only a third part of the population (32\%) had confidence in Russia's Government. The period 1995-1999 was marked by the highest level of no confidence in the Government (not fully credible; not credible at all). During these years, three-quarters of the population $(73-79 \%)$ believed that the Government was not credible.

The approval of the current Government's activities (certainly, or rather, yes) increased from $28 \%$ of respondents in 2005 to $62 \%$ in 2009 , with a subsequent decrease of this indicator to $49 \%$. Accordingly, in 2005, half of the population $(50 \%)$ did not approve of the activities of the Government. In subsequent years, the proportion of the population that did not approve of the activities of the Government decreased to $23 \%$ in 2008 , with a subsequent increase of this indicator to $42 \%$ in 2012 .

As a result of the changing outcomes of the polls, three groups of answers, characterizing the attitude to the current Government (negative attitude, positive attitude, hard to answer), were formed, and a general coefficient of the positive attitude of the population towards the Government was made (Figure 2). This coefficient was created from the difference between positive and negative evaluations. During the period 2003-2008 the outcomes of two polls overlap in time and differ, therefore the interval of the evaluating outcomes of these years is demonstrated by the dotted line.

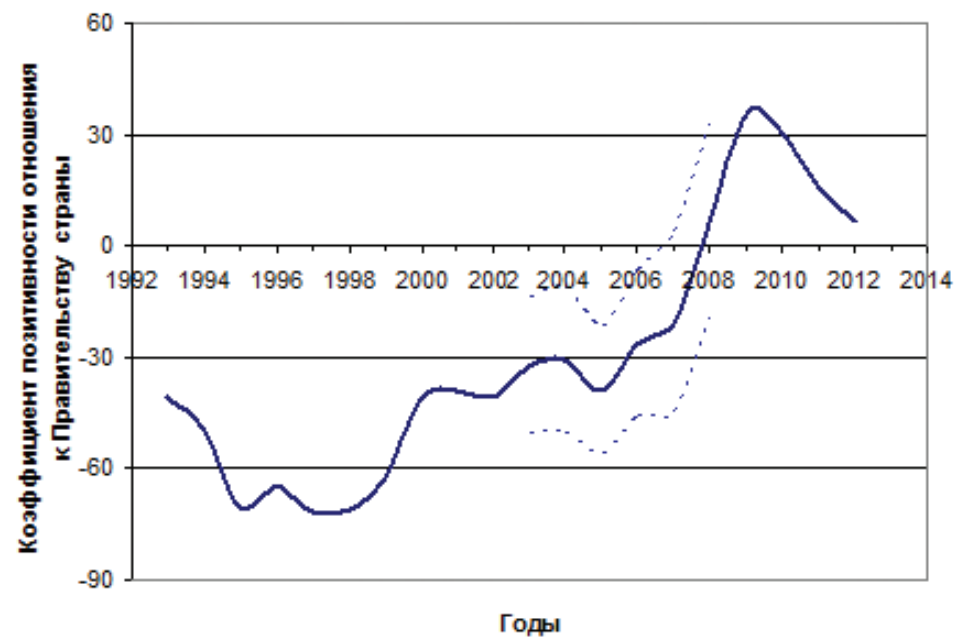

Figure 2. Ratio of the positive public attitude towards Russia's Government Sources: Perov, 2014.. 
Figure 2 demonstrates that the attitude towards Russia's Government was generally negative until 2008, but from 1999 the level of negativity decreased. And by the end of the period, it is obvious that the negative attitude turns into a positive one (Perov, 2014).

During the last 5 years, the rating of the President was consistently high and ranged from 60 up to $90 \%$. Such a high level of confidence allowed the President to make decisions and to implement them relying on the population despite the very high corruption level throughout the power vertical, including all the three power branches and police, prosecutor's services and so on proved by lots of cases. Even such unpopular activities as raising the retirement age, increasing taxes, amongst a number of others, were successfully implemented due to the speed of decisions and the non-resistance of opposition. Moreover, the opposition contributed to that process by dragging out the time through all kinds of referendums, non-essential meetings, protests, etc. This subjective basis demonstrates clearly the consequences of unpopular decisions. Thus, despite the successful implementation of controversial policies, the rating of the President collapsed and according to some estimates it at 27\% (39\%) of confidence. Further to this, there was a protest vote in the elections of governors, wherein a number regions the population voted contrary to the President's position.

\section{Conclusions}

It can be thus assumed that the volume of the power of the President can be expanded, as practice shows, through subjective means. Obviously, there are several important points. First, for democracy, it is necessary to regulate more strictly the volume of the President's power, since he does not belong to any power branch in the system of the separation of powers, but stands above them, which can lead to the usurpation of power, with absolute subordination to the President. Secondly, such deviation largely ensures the dependence of the political system on one official. Thirdly, when there is subjectivism in the framework of conditions of transition from the industrial structure of the economy and life to the postindustrial one, where the diversity of interests inevitably begins to dominate, freedom of information and the society's "demassification" might take place, according to E. Toffler. It can be however viewed as positive if mobilization for a breakthrough is needed, and as negative, if it will slow down the development of society. 


\section{References}

Abaeva, E. 2016. Modern Constitutional-Legal Regulation of the Organization and Activity of Presidential Plenipotentiary Envoy to Russia. Izvestiya of Saratov University. New Series. Series Economics. Management. Law 16(4), pp. 464-472.

Abdulbarova, J. 2019. Polnomochnye predstaviteli Prezidenta RF: harakteristika, osnovnye zadachi, funkcii, prava, http://fb.ru/article/362918/polnomochnyie-predstaviteli-prezidenta-rf-harakteristika-osnovnyie-zadachi-funktsii-prava (accessed 4.12.2019).

Chepus, A. 2015. The Government of the Russian Federation: the Composition and Procedure of Its Formation. Politics and Society 122(2), pp. 230-240.

Cherkasov, K. 2008. Institute of the Presidential Plenipotentiary of the Russian Federation in the Federal Districts: Characteristic and Place in the System of State Power of Russia. Modern Law 7, pp. 49-52.

Constitution of the Russian Federation. 2018. Moscow: ACT.

Gavrilko-Alekseev, A. 2018. Ot El'cina do Medvedeva: 11 glav rossijskogo pravitel'stva. $R B C$, https://www.rbc.ru/photoreport/07/05/2018/59de008a9a79477aadcae3f9 (accessed 4.12.2019).

Guseva, A., Pavlova, A. 2018. The tendency to expand the powers of the President of the Russian Federation as the determining factor of modern Russian statehood. In: A. Alexandrova (ed.). Actual problems of modern constitutionalism Materials of the III All-Russian Scientific and Practical Conference. Penza: Izd-vo PGU, pp. 113-118.

Kondratenko, E. 2017. Rating of the President of Russia as an indicator of the electorate's confidence in its activities. Theories and Problems of Political Studies 6(5a).

Krasnov, M., Shablinskij, I. 2008. Rossijskaja sistema vlasti: treugol'nik s odnim uglom. Moscow: Institut prava i publichnoj politiki.

Lebedintsev, I., Isakov, A. 2018. President of the Russian Federation in the system of power branches' divisions: institutional aspects of the implementation of powers. Society, economy, management 1, pp. 45-50.

Nevinskiy, V. 2018. Constitutional and legal regulation of the powers of the President of the Russian Federation in the formation of the Government of the Russian Federation. Russian Law: Education, Practice, Science 3, pp. 41-48.

Perov, E. 2014. The subjective image of the activities of the State authorities in the mass consciousness. Management issues 31(6), pp. 36-41.

Semenova, V. 2014. Return to direct elections of governors: new technologies of "managed" democracy. Izvestia of Saratov University. New Series. Series: Sociology. Politology 14(2), pp. 84-89. 